\title{
702 音響浮揚を用いた砥粒加工方式の考案および開発に関する研究 Study on development of acoustic levitation assisted abrasive machining method
}

\author{
○非 稲田 智広 （茨城大工） 学 箭内 善宇（茨城大院工） \\ 正 周 立波（茨城大工） 正 尾嶌 裕隆（茨城大工） 正 清水 淳（茨城大工） \\ Tomohiro INADA,Ibaraki University, Nakanarusawa 4-12-1, Hitachi, 316-8511 \\ Yoshitaka YANAI, Graduate School, Ibaraki University, Libo ZHOU, Ibaraki University, \\ Hirotaka OJMA, Ibaraki University, Jun SHIMIZU, Ibaraki University
}

\begin{abstract}
The phenomenon that the particle or the bubble is captured at nodes of standing wave by sound wave is widely known. Recently the phenomenon is theoretically clarified, and acoustic levitation technology is being established. If the acoustic levitation technology can be applied to the abrasive machining for control of the abrasive movement, an indispensable rotational and liner movement mechanism for the traditional abrasive machining become unnecessary, and the complicated machining in access, for example; the internal finishing of a tube, is able to be realized. In this study, we aim to proposal of a new method the abrasives with acoustic levitation, and develop a new polishing process that excludes machine movement mechanisms of driving. In this paper, the equation and condition of acoustic levitation is derived and acoustic levitation of a polystyrene foam is experimented.
\end{abstract}

Keywords: Acoustic Levitation, Abrasive Machining

\section{1.はじめに}

気泡あるいは球体が音波の定在波のノードの位置に捕捉さ れる現象は，以前から広く知られている．近年，その現象が 理論的に解明され，音響浮揚 (Acoustic Levitation) 技術が確 立されつつある．音響浮揚技術を砥粒加工に応用できれば, これまでの砥粒加工に不可欠であった回転運動や直線運動機 構が不要になり，管内面仕上げなどアクセスが極めて困難な 箇所の加工が可能になる.

本研究では, 音波を用いた砥粒の浮揚及び運動の制御方法 を考案し, 機械運動機構を必要としない新しい研磨方式を開 発する。

\section{2. 理論とシミュレーション}

Fig.1 のように音源である放射板と反射板間の距離 $L$ が音 波半波長 $\lambda / 2$ の整数倍になると，音響場内に定在波が形成さ れる. 1960 年に Gor'Kovが求めた定在波のポテンシャルUは, 音波の速度と圧力それぞれの実効值 $v_{\mathrm{rms}}, p_{\mathrm{rms}}$ の関数として次 式で与えられる(1).

$$
U=2 \pi R^{3}\left[\frac{p_{r m s}^{2}}{3 \rho c^{2}} \alpha-\frac{\dot{\rho} \cdot v_{r m s}^{2}}{2} \beta\right]
$$

ここで, $R$ は浮揚する球体の半径で, $\rho$ は空気の密度,

$c$ は空気中の音速である. ファクター $\alpha, \beta$ は次式で与える.

$$
\alpha=1-\frac{\rho c^{2}}{\rho_{s} c_{s}{ }^{2}}, \quad \beta=\frac{2\left(\rho_{s}-\rho\right)}{2 \rho_{s}-\rho}
$$

ここで, $\rho_{s}$ は球体の密度で， $c_{s}$ は球体中の音速である. 浮 揚する球体が剛体の場合， $\alpha=\beta=1$ となる.

一方, 定在波の粒子速度 $v$ 及び音圧 $p$ は, 次式のように与 えられる. 粒子速度と音圧を求めば，それぞれの実効值を求 めることができる.

$$
v=-\nabla \Phi, \quad p=\rho \frac{\partial \Phi}{\partial t}
$$

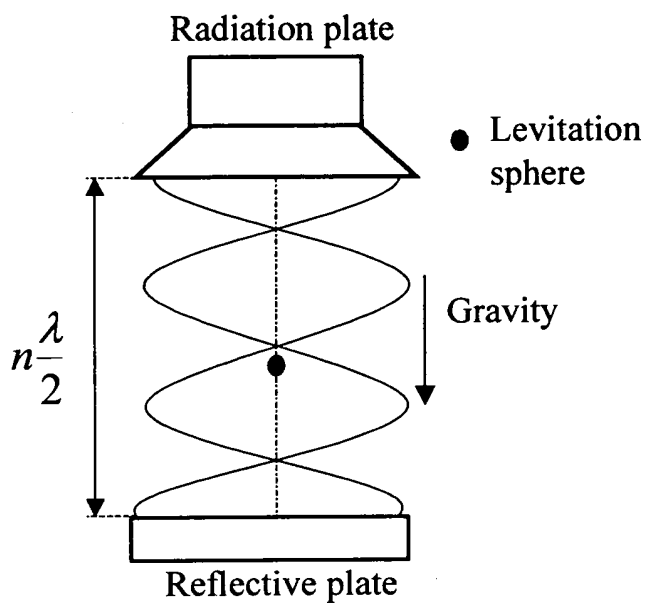

Fig.1 Concept of acoustic levitation

ここでは， $\Phi$ は速度ポテンシャルであり，次式により与えら れる.

$$
\frac{d^{2} \Phi}{d x^{2}}=\frac{1}{c^{2}} \frac{d^{2} \Phi}{d t^{2}}
$$

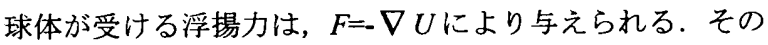
結果, 定在波のノード下部の位置に, 浮揚する球体の重力と 釣り合う点が存在する.

砥粒は一般に形状が軸対称でないため, 砥粒に垂直軸迴り にトルクが生じ回転運動する. また, 浮揚力が一定でないた め, 砥粒がさらに不安定な挙動を示す.この現象は, 球体を 安定的に浮揚させるには大きな問題となるが, 砥粒加工につ いてはメリットとして働く.

それに加えて, 音波の強度（振幅 $x_{0}$ ) を変えれば浮揚させ る砥粒の重さを, また音波の周波数 $f$ 変えれば浮揚の位置 を変えられることから, 音響場内における砥粓の運動制御が 可能となる.

本研究では音波の振幅, 周波数そして垂直軸の浮揚力につ いて調ベ，シミュレーションおよび実験を行った. 
まず, 球体が受ける浮揚力 $F$ を求める. 式（3）から粒子速 度と音圧を求め，その㥶効値を定在波のポテンシャル式（1） に代入し，その式の勾配を計算して以下の式を得る.

$$
F=\frac{5}{6} \pi R^{3} \rho v_{0}^{2} k \sin 2 k x
$$

ここで， $v_{0}$ は振動速度の最大速度で $v_{0}=x_{0} \omega$ である. 球体を浮 揚させるためには, その球体の重力は最大浮揚力より小さく なければならないので, 以下の式が成り立つ.

$$
\frac{4}{3} \pi R^{3} \rho_{s} g \leq \frac{5}{6} \pi R^{3} \rho v_{0}^{2} k
$$

上式は球体の密度と音波の周波数および振動振幅の関係を 表す式である.この式より振動振幅および周波数の境界を Fig.2のように示すことができる. 振動振幅と周波数がそれぞ れの対象物の曲線より上方であれば，その球体を浮揚させる ことが可能であることを表わしている。

\section{3. 実䍄と結果}

実験では放射板としてツイータを利用する.ツイータの振動 振幅は $100[\mu \mathrm{m}]$ と仮定すると, Fig.2 より $100[\mu \mathrm{m}]$ の振幅で周 波数 $5[\mathrm{kHz}]$ 以上であれば $\rho_{s}=0.05\left[\mathrm{~g} / \mathrm{cm}^{3}\right]$ の発泡スチロールを 浮揚させることができる. 今回は Table1 で示す, 直径約 $\phi 3$ $[\mathrm{mm}]$ で違う質量の 5 種類の球体を利用して浮揚実験を行った

実験では Fig.3 に示す装置を使用した. ツイータとアルミ反 射板の距離を $85[\mathrm{~mm}]$ で固定した。 パワーアンプはファンク ションジェネレーターの信号を増幅するために利用した。フ アンクションジェネレーターの周波数を $1[\mathrm{kHz}]$ から $20[\mathrm{kHz}]$ の範囲で変えることでノードの数も 1 から 10 に変えることが できる. 球体はノードの下位置で浮揚するため, そのノード に対応した周波数付近で微調整することで球体の浮揚を観察 した.

Fig.4 は実際に発泡スチロールが浮揚した時の様子である. 発泡スチロールにおいて, 理論では $5[\mathrm{kHz}]$ 以上を得るには, ード3(6[kHz]) 以上であれば良い。この条件で実験を行っ た結果, 発泡スチロールはノード 4,5 の時だけ浮揚した。， ード 3，6，7の時では浮揚はしなかったが，かなり激しい動 きが見られた。 また，発泡スチロール以外の球体では浮揚は せず，動きも見られなかった。

浮揚球体が円筒の軸上ではなく，円筒壁に沿って浮いてい た. その原因は半径方向にも力が働いているためと考えられ る. 今回は垂直軸方向の力のみを考虑して理論式を導いたが, 今後は半径方向の力も考慮する必要がある.

\section{4. 結言}

波動方程式から縋軸方向の浮揚方程式, 浮揚領域を導いた。 その結果浮場の際には振動数と振幅の大きさにより浮揚力が 変化すること分かった。 また実際に浮揚装置を作り, 実験を 行った結果ノード 4,5 の時発泡スチロールを浮掦させること ができた。しかし、ノード 6 以上では浮揚することはなかっ た.これは浮揚領域と浮揚球体の大きさがほぼ等しくなり,

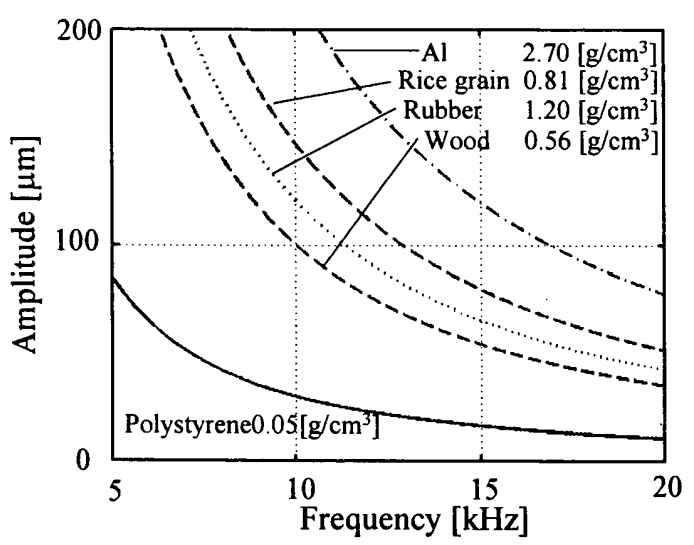

Fig.2 Amplitude parameter

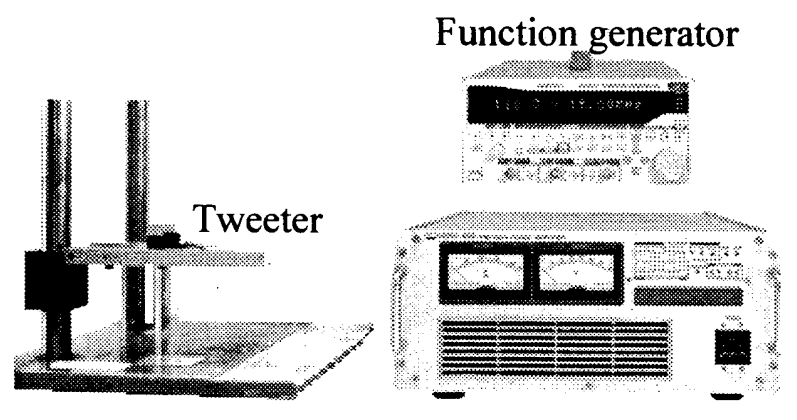

Power amplifier

Fig.3 Experimental setup

Table 1 Sample mass

\begin{tabular}{|c|c|c|c|c|c|}
\hline Sample & Polystyrene & Wood & $\begin{array}{c}\text { Rice } \\
\text { grain }\end{array}$ & Rubber & $\mathrm{Al}$ \\
\hline $\begin{array}{c}\text { Mass } \\
{[\mathrm{mg}]}\end{array}$ & 1.12 & 7.88 & 11.44 & 16.94 & 28.81 \\
\hline
\end{tabular}

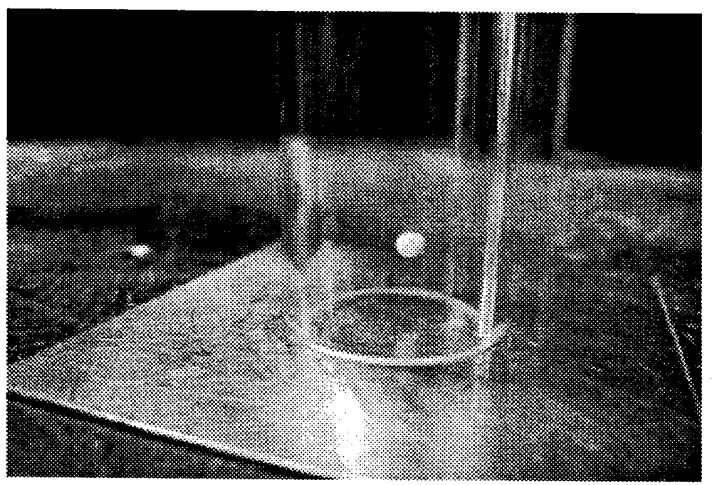

Fig.4 Levitation of polystyrene $(8 \mathrm{kHz})$

これ以上のノード数ではこれよりも領域が小さくなるため, 浮揚しなかったと考えられる.

参考文献

(1) Barmatz, M., P.Collas: J.Acoustical Society of America, 77 p.928-929 (1985) 